\title{
Teachers as Human Resources in Educational Organization of Transitional Societies, Indonesia
}

\author{
Dewi Wulan Sari*, Yayah Rahyasih \\ Administrasi Pendidikan \\ Universitas Pendidikan Indonesia \\ Bandung, Indonesia \\ *dwulans@upi.edu
}

\begin{abstract}
Development efforts of education are mandatory for every country to develop. Indonesia is a transitional country that has tremendous human resources. However, the distribution of them uneven. Therefore, there are a lot of gaps. In fact, Indonesia has unskilled human resources than skilled human resources. Less education is the main factor that reduces human resources who can use their potential properly, especially teachers. The teacher is the main component to raise the education goals so the quality of the teacher must be improved. The research method used a descriptive-analytic method using a qualitative approach and collecting data through observation, interview, and documentation from teachers as a research sample. The data source must be analysed and identified properly so, it creates a strategic design that can solve the world's challenges that are facing the revolution of industry 5.0 by observe various problems that come from everywhere. Education should be made in attractive ways by increasing the teacher's ability. The government must give more attention to the education sector so that educational goals can be achieved. This paper recommends that education standards in Indonesia should be updated to meet the rapid social changes and face the industrial era 5.0.
\end{abstract}

Keywords-human resources development, education, teachers, technologies

\section{INTRODUCTION}

Education is an important element and is a strategic aspect in the development and growth of the country. In supporting the era of world competition that is getting sharper as a result of globalization, Indonesia as a transitional country is required to achieve excellence towards a high level of national productivity. for that, there is no choice but to strive to improve the nation's ability to master science and technology and professional abilities, so that the nation can be equal with the developed countries in the world. It is a challenge for Indonesia to align the development and growth of its country, where the world is already in the industrial era 4.0 and towards the 5.0 era, namely on January 21, 20019 the Japanese PM office launched a roadmap known as the super-smart society or Society 5.0. This era is a human-centred and technology-based society order [1].
Technology as knowledge of the productive capabilities of corporate business [2]. That is, technology is anything that can support an increase in the productivity of individual performance in an organization. Five basic principles of the technological innovation process [2]:

- Technology should be conceived of as a competitive factor within a business system.

- New technological potential should be forecast.

- Technology forecasts should be implemented through planned technology strategies.

- New products using the new technology must be marketed with special attention to the problems of new markets.

- The technology strategy and business strategy must be closely integrated

The use of technology depends on human performance. Thus, excellence and innovation are created from the development of human and technological resources in an organization [3].

Such social, economic, political, religious and educational developments and changes can be faced by human resources who are always ready and dynamic in nature, so that they can adapt to the needs of the times. This is a challenge for teachers. As human educators, teachers must always improve and develop their skills, creativity and innovation so that they can create highly competitive human resources. National Education System Law No. 20 of 2003 states that education is a conscious and planned effort to create a learning atmosphere so that students actively develop their potential to have religious spiritual strength, self-control, personality, intelligence, social attitudes, and skills needed by themselves, society, nation and state [4].

The need for quality teachers must be addressed positively by teacher education managers. According to the 2019 Nations Development Program (UNDP), Indonesia's Human Development Index (HDI) scores quite high in the Asia Pacific. Based on these data, it is known that Indonesia's HDI is 0.707 
while other Asian countries such as the Philippines have an HDI of 0.712 and China of 0.758 . However, even so 17.4 percent of the HDI value in Indonesia is lost due to the larger inequality [5]. Inequality is a very important problem to overcome and has an important role in the development and growth of the country. Inequality that occurs can be minimized by developing human resources. The main objective of human resource development is to increase organizational efficiency by significantly developing technological knowledge, skills and expertise [6].

Stewart and Sambrook argue that HRD is currently under threat. Besides, HRD has evolved from its humble roots in the United States in the mid-20th century into an international phenomenon. The varied cultural, psychological, and organizational influences on HRD activities force a paradigmatic shift in understanding human development, and thus HRD [7].

\section{METHODS}

The study used a qualitative approach by conducting interviews and observations to analyse teachers' perceptions of human resource development (teachers) in the era of technology in education. Interviews and observations were carried out on teachers in an elementary, junior high and high school education institution so that they could produce a description of the analysis.

\section{RESEARCH FINDINGS}

The purpose of this study was to determine how the teacher's perception as a human resource that must be developed in the technological era. All respondents agreed to agree that in this era of globalization technology is very important that can be used in supporting learning media so that it is more attractive, but about $30 \%$ of them feel not ready for its implications. The teacher feels that he has many limitations when it comes to implementing technology properly. Many teachers do not have a tool or set of supporting media, their skills in using supporting media are limited to the time they have to learn a tool or set of learning media is limited. Not a few also make it difficult to learn and explore technology so that later it can be used as a new innovation.

\section{DISCUSSIONS}

Today, technology is no longer a strange thing in modern times, humans are required to be able to coexist with technology and make full use of it. Tulenheimo stated that there are challenges in implementing technology, including [8]: 1) customer needs, organization and company strategy; 2) competence and competitiveness of technology; 3) social aspects in the implementation; 4) the role of the developer and supporting elements. For details, see figure 1 on the main challenges in implementing technology.

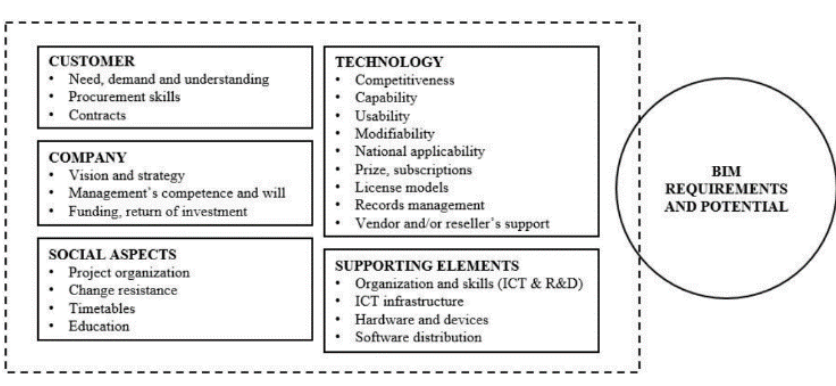

Fig. 1. Key challenges of implementing new technologies in the world of BIM.

The main challenge can represent the complexity that occurs in the environment so that decision makers must act immediately [8]. These main challenges must be conquered so that, with education, Indonesia can answer the challenges of the world and towards the 5.0 era. Interviews were conducted by Sukarni and Zarkan in 2017, it is known that a consultant named Dandi offers technology-based programs to determine human resource development [6]. The program is able to describe in detail the information from each employee such as performance evaluation, strengths and weaknesses, track records and can support decision making.

Technology has a significant impact on the development of human resources. However, in its implementation, technology does not only have positive but also negative consequences. R. Broderick and J. W. Boudreau stated that in addition to increasing productivity, technology implementation has an impact on the more time it takes to create an innovation and other quality problems [8,9]. The following table I is the impact of technology implementation according to experts.

TABLE I. IMPACT OF TECHNOLOGY IMPLEMENTATION ON HUMAN AND RESOURCE MANAGEMENT [10-13]

\begin{tabular}{|l|l|}
\hline \multicolumn{1}{|c|}{ Negative Impacts on HRM } & \multicolumn{1}{c|}{ Positive Impacts on HRM } \\
\hline Initial costs & Long-term savings \\
\hline Reduction in the headcount & Strategic role - new departments \\
\hline Data protection compromised & Time savings \\
\hline Outsourcing & Boosted savings \\
\hline $\begin{array}{l}\text { Responsibilities shifted to line } \\
\text { managers / employees }\end{array}$ & Standardization \\
\hline Blurring work / life balance & Enhanced performance \\
\hline Technological incompetence & Second life HRM source \\
\hline
\end{tabular}

The development of technology has now exceeded the perception of many people. Technology can reduce distances, map the earth, explore multiple issues and produce more effective and efficient products and services. Technology also has a role in developing innovative human resources, including:

- Jobs have been upgraded as an enhancement of intellectual's level is required to handle most of the jobs hitter to be handled by unskilled or semi-skilled workforce. 
- Highly technical jobs have produced in displacement of people unless they have kept pace with the technological development.

- The job will be challenging and rewarding. For those employees who pick up and acquaint themselves with new technology.

- Technology has attributed development and promotion of human relations. Introduction of team work, quality control teams are outcome of technology human interface.

- Job holders have become highly knowledgeable and hard core professionals. Organizations have become "techno-structure" having an idea al combination of scientists, technocrats and management specialists.

\section{CONCLUSIONS}

Digital transformation has revolutionized the way an organization deals with customers, how organizations carry out operations, how organizations understand models and manage internal rules. The integration of digital technology in organizational services can change the way the organization works. The integration of digital technology is very important for the livelihood class and the competitive advantage of contemporary organizations. Technology can significantly influence the development of human resources, apart from having a positive impact, the implementation of technology also has a negative impact. This has resulted in policy makers always being wise in implementing it and full of consideration.

Human resource management has a major focus on organizational performance which emphasizes the role of human resource management as a solution to business problems. Human resource management is a strategic asset for a company that contributes to the company's competitive advantage. Human resource management in the digital era has become more varied and more individual-oriented with the responsibility of designing diverse and challenging jobs to make young employees more involved in their work.

Efforts that can be made to minimize the gaps that occur are by holding technology training, especially in making learning media, the intention is to be further improved, besides that it can also create small study groups carried out by teachers in order to improve their ability to use technology media so that learning can stimulate students in developing the potential it has. Provision of technology is also an important thing that must be done by policy makers.

\section{REFERENCES}

[1] I. Sabri, "Peran pendidikan seni di era society 5.0 untuk revolusi industri," In Seminar Nasional Pascasarjana 2019. Universitas Negeri Semarang: Semarang, 2019

[2] F. Betz, Strategic technology management. New York: McGraw-Hill, 1993.

[3] C. Hughes, "People as technology" conceptual model: toward a new value creation paradigm dor strategic human resource development," Human Resource Development Review, vol. 9, no. 1, pp. 48-71, 2010.

[4] Undang-Undang Sistem Pendidikan Nasional No. 20 Tahun 2003.

[5] K. Saitri, UNDP: Untuk Pertama Kalinya, IPM Indonesia Masuk Kategori Tinggi [Online]. Retrieved from: https://money.kompas.com/read/2019/12/10/190621026/undp-untukpertama-kalinya-ipm-indonesia-masuk-kategori-tinggi?page=all, 2019.

[6] S. Sukarni and I.A. Zarkan, "Human Resource Development in The Era of Technology: Technology's Implementation for Innovative Human Resource Development," Jurnal Managemen Teori dan Terapan, vol. 10, no. 3, pp. 217-223, 2017.

[7] J. Stewart and S. Sambrook, "The historical development of human resource development in the United Kingdom," Human Resource Development Review, vol. 11, no. 4, pp. 443-462, 2012.

[8] R. Tulenheimo, "Challenges of implementing new technologies in the world of BIM- case study from construction engineering industry in Finland," Procedia Economic and Fiance, vol. 21, pp. 496-477, 2015

[9] R. Broderick and J.W. Boudreau, "Human resource management, information technology, and the competitive edge," Academy of Management Perspectives, vol. 6, no. 2, pp. 7-17, 1992.

[10] A. Hendrickson, "Human Resource Information Systems: Backbone Technology of Contemporary Human Resources," Journal of Labour Research, vol. 24, no. 3, pp. 391-392, 2003.

[11] H. Ruel, T. Bondarouk and L. Looise, "E-HRM: Innovation or Irritation An Explorative Empirical Study in Five Large Companies on Web Based HRM," Management Revue, vol. 15, no. 3, pp. 367-378, 2004

[12] H. Sushi, "Out of This World. In: People Management. ISSN 13586297. (2015, May 23)," The Role of Technology in Human Resource Development, 2015.

[13] E. Parry and S. Tyson, "Technology in HRM: the means to become a strategic business partner," Human Resource Management, Thomson Learning, pp. 235-249, 2007. 